\title{
The Plight of Foreign Workers in Japan: Their Stories Speak for Themselves
}

\author{
Rong Zhang ${ }^{1}$ and Dennis McCornac ${ }^{2}$
}

\begin{abstract}
Japan's demographic changes over the past decades have prompted a sea change in immigration policy. Once such effect has been the influx of foreign labor to address labor shortages in various sectors of the economy. The purpose of this paper is to examine the recent situation of foreign workers in Japan who have been impacted by these immigration policies, particularly considering the coronavirus pandemic. We present the results of in-depth interviews with such individuals to provide insight into their working and living conditions. We conclude that to date, the new immigration system has failed to live up to expectations, and if Japan wants to accept more foreign workers to boost its economy and realize faster progress in globalization, more efforts need to be made at both the national and local levels.
\end{abstract}

Keywords: Foreign labors; migration; globalization; Japan

\section{Introduction}

Japan's demographic changes over the past decades have prompted a sea change in immigration policy that may portend significant impacts on Japanese society. In April 2019, Japan opened its door to unskilled foreign workers for the very first time in history. Under the new system, it has been forecasted that up to 345,000 blue-collar workers would come to Japan to work in 14 sectors by 2024 (Koizumi et al., 2019).

This new system has been designed to address the severe labor shortages created by the declining birth rate and the "graying" of Japanese society. Scarcity in industries such as restaurants, hotels, leisure and tourism, and construction is prevalent with the healthcare sector particularly impacted. Taking care of the elderly population, for example, will not only require individuals skilled in caregiving, but also familiar with the language and culture. This, however, may present the biggest challenge in hiring foreign workers as culture clash is expected to have major effects.

More than two years into the implementation of this system, however, only a fraction of these workers has been hired. Although the effects on the economy of Japan due to the Covid-19 pandemic have significantly impacted the hiring of foreign workers, the reluctance of firms to hire has already started. The slow pace has raised questions about the extent of reforms likely by a country that has long taken a guarded view of immigration (Milly, 2020). Nevertheless, immigration is a necessary policy if Japan is serious about addressing its severe labor shortage.

The purpose of this paper is to examine the recent situation of foreign workers in Japan who have been impacted by these immigration policies, particularly considering the coronavirus

\footnotetext{
${ }^{1}$ Rong Zhang, Nishinippon Institute of Technology, Japan. E-mail: zhang@nishitech.ac.jp.

${ }^{2}$ Dennis McCornac, Georgetown University, Qatar. E-mail: dm123@georgetown.edu.
} 
pandemic. We present the results of in-depth interviews with such individuals to provide insight into their working and living conditions. We conclude that to date, the new immigration system has failed to live up to expectations, and if Japan wants to accept more foreign workers to boost its economy and realize faster progress in globalization, more efforts need to be made at both the national and local levels.

\section{Impetus for Policy Changes}

To better understand the impetus for the latest changes in immigration policies, it is important to examine the migrant labor issue from a historical perspective. Of particular significance is the rapid pace in the decline and aging of the population in Japan which continues unabated. Although precise future population numbers are impossible to calculate, an earlier study by the Population Division of the U.N. Department of Economic and Social Affairs (2015) estimated that the population of Japan will dip below 100 million shortly after the middle of the 21 st century and by the end of the century, Japan stands to lose 34 percent of its population. With the pace accelerating in subsequent years, Harding (2019) described the country as being set to lose the equivalent of a midsized city every year for the foreseeable future.

The coronavirus pandemic has further exacerbated the decline, and data by the Japan Research Institute put annual births at 848,000 in 2020 and close to 800,0000 in 2021, a third of the levels seen during the postwar baby boom (Nakamura, 2021). Projections of continuing declines in birth rates are evidenced by the tumble in the number of marriages during the coronavirus pandemic. In 2020, for example, Japan saw only 537,583 marriages, a $12.7 \%$ fall from a year earlier - the biggest percentage drop since a $15.1 \%$ tumble in 1950, when a postWorld War Two marriage boom began to fizzle out (Takenaka, 2021).

In tandem with the declining population is the graying of Japan, and the nation currently is one of the most aged societies in the world. The ratio of people aged 65 and older is expected to rise to 31.6 percent by 2030, a close to nine percentage point increase from 2010. Over the same period, the ratio of the productive-age population comprising people aged 15 to 64 is expected to fall to 58.1 percent from the earlier 63.8 percent. This implies that by 2030 there will be just two workers supporting each elderly person, and by 2060 this figure will drop to 1.2 workers (National Institute of Population and Social Security Research, 2016).

\section{Watershed Response}

Although various temporary policies over the years were enacted to address labor shortages resulting from these demographic changes, what may turn out to be a watershed moment for Japanese society occurred on December 8, 2018. On this date, the upper house of Japan enacted a sweeping new immigration policy that allowed for the acceptance of unskilled foreign workers to Japan on a more permanent basis. Despite the resistance from opposition parties (Mainichi, 2018), it was estimated at that time that up to 345,150 foreigners will enter the Japanese labor market and work as unskilled workers within the coming 5 years.

In April 2019, Japan officially enacted a new law which showed the potential for the trainees to stay in Japan after their internship. A new visa type, provisionally named "Specified Skills"

\section{Border Crossing}


(Tokutei ginou，特定技能) was the first move to open Japan's doors to the much-needed additional foreign labor.

In the original announcement, the government proposed to allow more than 500,000 foreign workers to be employed in five industries by 2025. These industries were agriculture, nursing care, construction, ship building and lodging and hospitality. In a significant departure from current laws, the visa requirements would not include a degree and would allow holders to have the chance to upgrade to permanent residency in Japan (Carrigan, 2018). The two visa statuses, to be labeled Specified Skills 1 and Specified Skills 2, were designed to potentially apply to 14 industries in total. The working and long-term stay visa categories are outlined by the Ministry of Foreign Affairs Japan (2019) and comprehensive discussion of the new immigration scheme can be found in Milly (2020).

The law has been a major first step in allowing more foreign workers to settle in the country. It is an issue of crucial significance for Japan as it will require Japanese society to accommodate foreign workers and help them to get involved in the society as a host country.

\section{Foreign Workers with Legal Status - The Original Classification}

Until the recent change in policy, there had been several ways for foreigners to work legally in Japan: (1) Foreigners could obtain a working visa as professionals and skilled workers. This included occupations such as interpreters, technicians, educators, pilots, and cooks; (2) Foreign students were allowed to work as part-time, with a limit of 28 hours per week during school days and 8 hours per day during vacation. (3) Unskilled workers could contract with a company and become trainees. Technically, these individuals were not employed, but rather conducting training activities. It is by this method that foreign workers had been exploited to solve the problem of an unskilled labor force shortage within the country.

\subsection{Students}

Regarding foreign students, the high college tuition fees, and cost of living in Japan required these individuals to do part-time jobs to meet expenses. While the Japanese government issued specific certificates to supervise the working time of the foreign students, many were forced to work extra hours beyond the maximum limit.

The initial recruitment of foreign students began in 1983 as a result of Prime Minister Yasuhiro Nakasone's proposal to increase the number of international students enrolled in Japanese universities and colleges to 100,000 by the beginning of the 21 st century. The stated goal of this program, however, was not to address any labor shortage, but rather to aid in the "internationalization" of Japan and graduates were expected to return to their home country after graduation.

A major change in this program occurred in 2008, however, when Japan revised its goal in foreign student recruitment and increased the recruitment target to 300,000 (Hennings and Mintz, 2015). The Japanese government also adjusted the purpose of the policy and started promoting the employment of foreign students in Japanese companies. This was considered one of the initial measures to solve the problem of a lack of unskilled workers in its domestic labor markets. Since most of these students come from developing countries, they are more willing to get involved in unskilled work to pay tuition fees and life expenses. The labor 
provided by these individuals has significantly compensated for the shortage of domestic labor.

The success of this change, at least from the standpoint of addressing the labor shortage, can be evidence by the rapid increases over the past decade of international students in Japan, particularly in the number of students coming from Asia. According to data from the Japan Student Services Organization (2020), in 2019, nearly two-thirds came from only two countries: China (40\% of the total, sending 124,436 students, up $8 \%$ over 2018) and Vietnam (24\%, sending 73,389 students). Rounding out the top five sending markets for Japan were Nepal (8.4\% of the total, 26,308 students), South Korea (5.8\%, 18,338 students), and Taiwan (3\%, 9,584 students).

\subsection{Technical Intern Training Program (TITP)}

In 1993, Japan started the Technical Intern Training Program (TITP). According to the guidebook issued by the Japan International Training Cooperation Organization (JITCO, 2010):

The Technical Intern Training Program (TITP) is a program where young workers from various overseas countries acquire industrial and vocational skills as technical intern trainees at companies in Japan, and then improve their acquired skills through further two years technical intern training, so that they can utilize such skills for economic and industrial development after their return to home countries. In other words, the TITP aims to develop human resources who can contribute to the industrial development of foreign countries through transfer of Japanese technology."

Thus, the stated purpose of the program was for Japanese companies to accept trainees to help them to master highly advanced technology so that they can contribute to the development of their own country in the future. Basically, the trainees could stay with one employer for three years and then once the skills are developed, they must return to their home country. At this point in time, the contract between the intern and the company expired.

The real intention of the changes in the recruitment of students in 2008 and the original purpose of the TITP, however, has proven to be somewhat different that stated.

\section{The Concepts of Honne-Tatemae}

To better understand the impetus for the changes in the student recruitment policy in 2008 and the nature of the TITP, it is important to comprehend the Japanese socio-psychological concept of honne-tatemae. Furuoka and Kato (2008) note that Honne means "the real intention" while tatemae signifies "façade" or "appearance." Kopp (2014) further elaborates that honne could also be referred to as "the actual situation" or "the story behind the story" or "the unvarnished version" and tatemae could be referred to "the line for public consumption", "a white lie" or "a euphemism."

In the situation of Japan's foreign aid, for example, Furuoka and Kato (2008) reason that Japan ostensibly uses its foreign aid for altruistic reasons, such as the promotion of development and prosperity in the international community. Although this altruism can be viewed as a superficial principle of Japanese ODA, and which forms the 'tatemae' dimension. The primary motivation for Japanese foreign aid policy is to support the Japanese commercial sector and is mostly aimed at benefiting Japan's own economic well-being. These selfish 
motives can be considered as the hidden principle of Japanese aid giving activities that forms the honne dimension (Furuoka and Kato (2008).

Applying this concept of honne-tatemae to the situation of foreign students in Japan it is not difficult to see evolution of the reality of the stated goals of the program. This project's original aim was to "make Japan a more open country, encouraging interpersonal exchange by establishing a study environment to attract foreign students." And for a number of years, the tatemae - promoting foreign students to study in Japan- was consistent with the honne the stated goal.

Serizawa (2018), postulates that the first divergence from this goal came when the government allowed foreign students to hold part-time jobs. Under the law, people on a student visa could work "in principle" up to 28 hours per week. The limit comes "in principle" because during summer vacation and other such times, the students can work up to 40 hours per week. This standard is very lax compared to other countries, which do not allow people on student visas to may not hold jobs at all.

Thus, the honne aspect of the program changed. While promoting a program that encourages the internationalization of higher education is one goal, the true purpose of the program morphed into utilizing foreign students to address the country's severe labor shortage. Serizawa (2018) notes that more than 90 percent of foreign students do some kind of job while in Japan.

Gracia and Tran (2019) argue that the education-migration industry in Japan emerged because of the discrepant institutional logics. Japan's reluctance to open the door for labor import, despite its acute labor shortage, has turned international education into a sanctioned channel of labor migration and thereby created opportunities for international education to become a thriving migration industry.

The concept of honne-tatemae can also be applied to the Technical Intern Training Program. The original stated purpose of the establishment of the TITP (the honne) was to highlight the potential benefits the trainees would contribute to their own countries after they return to their homeland. Initially, and until the beginning of this decade, both the stated and actual purpose of the program were in agreement. However, over time it became all too obvious that the true purpose was to serve the interest of Japanese companies in their quest for unskilled labor. Many Japanese companies have taken advantage of this system to import cheap labor from abroad. Trainees have often subjected to harsh working conditions, paid much less, and forced to work longer hours than legal under the law. (Foreign workers in Japan and Problems with Japan's Foreign Trainee Program, 2013). The rights of the workers are not sufficiently protected, and the unskilled workers are just being used for a temporary purpose under the current intern and trained program (Fan, 2012; Bhattacharjee, 2014; Verité, 2018, ASSC, 2020). This situation has existed, and continues to exist, because Japanese companies find it necessary to take advantage of this cheap labor to survive in a severely competitive environment. 


\section{Literature Review}

Although the government of Japan has made efforts to improve the environment for migrant workers, discrimination, and social stigma continue to exist and more needs to be done. A survey in 2017, for example, conducted by Japan's Ministry of Justice among 18,500 migrants living in Japan revealed that $30 \%$ had experienced discrimination, $40 \%$ were rejected for rent by landlords, and 25\% were denied a job on the basis of their nationality (Japan Ministry of Justice, 2017).

The effects of Covid-19 on migrant workers in Japan have not been well studied due to the on-going nature of the pandemic. The most comprehensive study to date is Bhandari et.al (2021) which, using interview data, examined the challenges faced by Nepalese migrants living in Japan. The author's note that the immediate challenges faced by participants relate to financial shortfalls arising as a result of the pandemic, including difficulty in paying rent and tuition fees, loss of wages, and difficulties in conducting business. Foreign workers, however, particulary those on short-term contracts are laid off first," because they're easier to fire" (BHRR Centre, 2021).

These factors have contributed to anxiety on a number of different levels and the lack of social support, the language barrier, etc. negatively affects the health and livelihoods of nonJapanese in Japan. The Covid-19 pandemic has only exacerbated their vulnerability (Bhandari et.al, 2021). Yusaku Yoshikawa, writing in the East Asian Forum (2021) notes that besides COVID-19 infections and a decrease in income and layoffs, the impact on foreign workers comes in various other forms. For some, visa renewals are a challenge and can lead to repatriation. Others have been involuntarily detained in Japan due to reduced flights to their homeland and financial hardship. Thus, it is necessary to develop a nuanced understanding of these impacts because the visible influences are almost certainly just the tip of the iceberg. This should include greater government efforts to pinpoint the impacts and vulnerabilities facing foreign workers to identify possible remedies (East Asian Forum, 2021).

The situation of migrant workers must also be examined in the context of the degree of country and individual attitudes and reactions to immigration as countries find themselves in need of more migrant workers. Understanding the main drivers of people's views on immigrants and on immigration policy can provide remedies for some of the social problems that can be associated with hostility to immigrants, such as discrimination, poor social integration and support for xenophobic political forces.

Davison and Peng (2021) note that research on the determinants of people's attitudes toward immigration has largely focused on two main strands of explanations: the interests approach and the identities approach. The first is primarily based on the perception that due to the willingness of migrant to accept lower pay, these workers will compete with the local population and depress wages and job opportunities. This will strain the social fabric and are often cited as examples of reasons for anti-immigrant attitudes (Kessler and Freeman 2005; Meuleman, Davidov, and Billiet 2009). Hamada (2013), for example, found that low-skilled workers are less likely to support pro-immigration policies in Japan because they think immigrants will compete with them for jobs.

The second explanation is the identities approach. Migrant workers are also often perceived to represent different values and traditions and pose a threat to the "national identity" or the traditional "way of life" (Citrin and Sides 2008; Fussell 2012). Taking care of the elderly

Border Crossing 
population, for example, will not only require individuals skilled in caregiving, but also familiar with the language and culture. Japan, however, is proud of being a mono-lingual and monocultural country (Zhang and McCornac, 2013).

Given the changing demographic situation in Japan, it would appear that the identities approach would be the dominant factor. The need for Japan to import labor to support it economy has certainly been necessary prior to the Covid-19 pandemic. However, in certain sectors of the economy, education for example, our interview data has shown this is not necessarily the case. Nevertheless, this study provides evidence that the identities approach is the predominant factor.

It must also be noted, that the issue of labor shortages and the need to increase immigration are not unique to Japan. South Korea's SMEs mainly need workers in agriculture, fishing, manufacturing, and construction, among other blue-collar sectors, which are inherently mismatched with the employment expectations of South Korean young adults. In 2004, South Korea implemented a formal guest worker program known as the Employment Permit System. This was in response to calls for greater regulation as prior to this time, there was an both an informal and technically illegal market for foreign labor as the country's borders remained officially closed to unskilled immigrants (Stokes, 2021).

This impetus for allowing migrant workers to enter, a result of South Korea's demographic trends, corresponding initiatives to address them have challenged long-held conceptions of nationhood based on claims of ethnocultural purity. While the country has continued to open itself to immigrant workers due to demand factors, the system has numerous flaws (Chung, 2021). Migrant workers who enter South Korea through the EPS are legally tied to their employer and are not allowed to bring dependents.

These rules make documented migrant workers vulnerable to exploitation as their presence in South Korea and documented status are dependent on the honesty and kindness of their employer. If the employer decides to take advantage, there are often few recourses, as proving mistreatment can be challenging in an unfamiliar legal system. They also lack the emotional support provided by having family present. There are many cases of documented migrant workers being underpaid, having their passport withheld, being forced to work unpaid overtime, or being verbally, physically, or sexually abused (Hyun-ju, 2017).

Migration is also a very critical issue in the Gulf, particularly in countries like Qatar, UAE, and Saudi Arabia. If all countries in the Gulf Cooperation Council (GCC) are considered, the foreign population in the GCC slightly outnumbers - by $51 \%$ - the local population. While Saudi Arabia have managed over the years to maintain a higher share of natives $(63 \%)$ in their overall population, others like Qatar $(14 \%)$ or the UAE $(11 \%)$ score the lowest in terms of ratio of natives over foreigners in their total population (Kenny, 2021). Unfortunately, the treatment of migrant workers in this region has been one in which these workers have often been exploited and abused. Only recently have the governments begun to reform the labor practices that have discriminate against and infringe on their human rights. On a positive note, the region has recently begun to reform with Saudi Arabia giving foreign workers the right to change jobs by transferring their sponsorship from one employer to another, as well as leave and re-enter the country and secure final exit visas without the consent of their employer. Qatar has introduced similar reforms (Aboueldahab, 2021). 


\section{Methodology}

While the plight of foreign workers in Japan has been less than desirable for decades, the recent pandemic has only worsened their situation. The economic recession has resulted in lost employment opportunities. Those that have lost jobs have given up searching for new ones due to the lack of employment opportunities. However, they cannot go back to their home country because of flight restrictions. Many are in a state of limbo do not know what next steps to take. Further complicating the situation of the worker is the debt that is often owed to recruitment agencies who assisted them in initially coming to Japan. (Weekly Economist Online, 2020).

According to a survey by Yolo Japan (2020), close to $80 \%$ of foreign workers report being affected by the coronavirus pandemic. Issues related to their financial situation, and how to obtain a job to maintain their legal status in Japan were of particular concern. For certain workers, once they are hired by a company their employment status is reported to the immigration bureau and they are prohibited from doing jobs which are not included in their visa type. Once their employment ceases, the visa becomes invalid. Thus, they must apply for a new working visa each time they find a new job.

To better understand the situation of migrant workers in Japan, particularly in light of the coronavirus pandemic, this paper reports on the results of in-depth interviews with a number of foreign employees at various establishments in Kitakyushu, Japan. We examine the conditions from the perspective of the foreign worker analyzing problems related to both their work and private lives. The worker's stories are presented in narrative form with the intention of giving the reader the opportunity to understand the lives of foreign workers from the worker's viewpoint.

The data sources for this study are both formal and informal first-hand interviews conducted by one of the authors of this study who is fluent in English, Chinese and Japanese. Fifteen individuals, all who reside in or around the city of Kyushu, Japan represent workers who came to Japan on various type of visas. Among the fifteen foreign workers, five are females and ten are males. They come from China, Vietnam, Nepal, India, and the USA. Seven of them are students; eight are working in Japan as cooks, small business owners, trainees at construction sites and long-term English teachers. In a semi-structured setting, the interviewees were questioned about such issues as current lifestyle, financial status, history in Japan, personal and professional relationships, as well as current emotional situation. All parties were encouraged do speak openly and freely with no limitations on content or time. Each was assured that the information would remain confidential, and their family or company names would not be revealed. Thus, the names of the individuals are changed in this study. A representative sample of those interviewed is discussed below.

\section{Sample of Individuals Interviewed.}

The Student from Vietnam (NHL) - Nguyen Huong Lien. I came to Japan in 2016. After learning at the Japanese language school for about 2 years, I became a university student majoring in engineering. I want to become an engineer after graduation. 
The Student from China who Stayed (XD) - Xingyu Duan. I am a 36-year-old make from China. I came to Japan in 2008 when I was 23 years old. I finished my Japanese study at the pre-course and the four-year study at a local university. When I graduated from college, a company helped me to obtain a working visa and I have worked at various companies ever since. I am now married.

The Indian Recruited for His Culinary Skills (RK) - Rajendra Kumar. I am 23 years old male from India. I finished my junior high school in India and started working as a cook. About one year and a half ago, I heard that an Indian restaurant in Japan was looking for a cook. My friend in India introduced me to the owner. I arrived in Japan in December 2019 and the restaurant was scheduled to open in March 2020. Because of Covid-19, the owner postponed the opening. I was told to wait. I have not learned much Japanese and understand only some greeting terms. I have a working visa, but the visa is restricted to working at that restaurant only.

The Small Businesswoman from China (XW) - Xueying Wang. I am from China and I am 34 years old. Both my husband and I came to Japan on student visas and we started our small business right after graduating from college. At that time, we did not succeed in job-seeking and decided to obtain a visa for investors. We invested about 50,000 dollars and own and manage both a small shop selling Chinese food materials and a small Chinese restaurant. We have a six-year-old daughter.

The Long-Term English Teacher (JM) - Joseph Miller. I am 54 years old. I have an Ed.D in TESOL. I came to Japan in the early 1990s, as an Assistant Language Teacher (ALT). I contracted with a company for English training and was dispatched to different junior and high schools. I am married and we have two children. My wife also teaches English.

The Intern (AK) - My name is Anish Kamel and I came from Nepal to Japan in the Technical Internshop Training Program. I work in the rural area on a farm. I am in the second year of a five year contract.

\section{Discussion of Stories}

Mr. Lien (NHL) and Mr. Duan (XD) are two indiviuals whose stories provide clear evidence of the honne-tatemae nature of the program to internationalize the education system.

(NHL) The tuition fee is too high. The school offered me a reduction, but I still must pay about 8000 US dollars per year. My family paid the tuition fee for the first year of my stay, but after that I must manage my life expenses and the tuition fee by myself. I have done a lot of part-time work since I came here - at a fishprocessing factory, a box-lunch factory, a supermarket, a convenience store, and a gasoline stand. So, I had to work at the factory on the night shift. At the beginning, I was not very good at Japanese language. Then I passed the $1^{\text {st }}$ level of the Japanese Language Proficiency Test. Although I was able to work at other places, I still chose to keep working at night to earn money.

While the Japanese government grants these students the right to take on part-time positions to help address the issue of the labor shortage in Japan, Mr. Lien finds himself in financial difficulties that force him to work long hours with little time to study. Mr. Duan (XD) from China, who came in 2008 and were fortunately able to complete both Japanese language training and obtain a four-year degree also worked several part-time jobs to enable him to pay his tuition and living expenses.

(XD) When I was a student, I worked at several places: at a car-fixing factory, at a convenience store, and then at a factory which produces bean sprouts. After working there for more than one year and a half, I graduated from college and the company helped me to obtain a working visa and I stayed with them for another year and $a$ balf. 
There appears to be a certain degree of exploitation and once these individuals arrive many become more like indentured servants, particularly those on being a student to keep their visas and individuals on a student visa often find it necessary to take on part-time work to enable them to earn enough to survive in Japan. Employers appear to have exploited this situation for the benefit of finding cheap labor.

The reality is that education is generally not at the top of the list of motives for recruitment of students. The declining population of college-age students in Japan have forced Japanese Universities to admit an increasing number of international students to fulfil admission quotas. Many universities have looked abroad to places like China and Vietnam to fill their ranks. Given that Japanese universities are not that challenging (McCornac and Zhang, 20132), many are more concerned with keeping students, and grades are inflated to keep students enrolled.

Yoshimitsu Sawa, (Kakuchi, 2019), emeritus professor at Saga University, notes that the goal of internationalization of Japanese universities has not come to pass. "Instead of turning out brilliant students, we have a situation where foreign students gain visas and provide cheap labor in a Japan that faces a severe blue-collar employment crunch ... Too many universities in Japan cannot manage financially due to dwindling Japanese student numbers as the national population drops."

Japanese language schools are particularly notorious as primarily a means to bring in foreign students who are then forced to take on multiple jobs to enable them to stay in Japan. Although the situation is mutually advantageous for both parties (cheap labor for the firm and a job for the student) it does give the employer the upper hand due to the threat of losing the visa. Thus, the foreign student is more a worker than a student, which is the real reason, or honne for bringing in foreign students. Many students are not able to complete their course study as scheduled and feel disappointed when they realize that they had not been told about the truth before coming to Japan.

(NHL) It is going to be a new academic year and the time for paying the tuition fee. I must gather money for that. The worse thing is that I failed in the final test in one of the required courses. I worked too much to obtain the tuition fee but was absent from classes or just slept. Most probably, I will have to stay for one more year before becoming a senior student. In that case, I will have more time to work and save money. But the problem is that I might not be able to renew my student visa. I have lost one part-time job because of the pandemic and certainly do not have the money for a lanyer to belp me do so.

A number of other individuals who came to Japan as students who were interviewed for this study had similar stories of difficulties paying for tuition and the need to resort to various part-time jobs to service. And this has persisted for a long time.

This is not to say that there are not some positive outcomes for students who come to Japan. Mr. Duan (XD), for example, was able to change his visas status upon graduation and has remained in Japan for close to fifteen years. However, it has not been easy, and his story below highlights a number of social and cultural obstacles and challenges.

(XD) After working there for more than one year and a half, I graduated from college and the company helped me to obtain a working visa and I stayed with them for another year and a half. I got married while working at the bean sprout factory. When I was there three interns from China were also employed. They worked in shifts, so the machine was operating 24 hours a day. The owner of the factory asked me to help teach the intern

Border Crossing 
workers since all of them didn't speak much Japanese. I was also told to deliver the bean sprouts to the retail outlets, so I got the chance to talk with the managers there. Then I learned that the head of my department was trying to cheat our company by putting some money into his own pocket. Once he realized that I had known about his secret, he told me that we could split the profit. I did not want to lie and betray my company. So, I decided to quit the job after working there for three years though I was the only one supporting my family. My danghter was only one year old, and my wife took care of her.

I transferred to a construction company The company was a middle-size business with less than 200 employees, and one-third were foreigners from China and Vietnam. The president was hoping to expand so that he could acquire the permission from the government to hire more TITP interns from abroad. Interns are cheaper than formally bired workers. The company does not have to pay for some insurance for the interns. So, the president and the managers were very strict with $u$ s.

As the number of foreign workers increased, the president realized that it would be a great threat if all the foreigners unite and fight for better compensations. He deliberately created big gaps in salary and other benefits among foreign workers although they do the same work. According to the law, workers should have a pay raise every year. But he refused to do this sometimes. I was relatively older than most of other foreign workers, so sometimes I would talk with the president for potential improvement of the salary and other benefits for workers. Sometimes he agreed with our demands, but this quite often the effort was futile.

This relationship with the president eventually became troublesome, as he was concerned I would bring trouble for him because I was the leader among the workers. Subordinates in Japanese companies do not question management. The president made efforts to destroy the trust between me and other workers. At the end of 2019, our company did realize a good profit, and everyone received a good bonus, except me. When I asked him the reason, he replied that I could leave if I was not satisfied. I realized that the situation would be worse for me if I stayed there. So, I told bim that I would quit the job. But this was not possible, and I could only leave six months later.

The pandemic did not initially have a serious impact on the construction industry since most of the contracts were signed before that. We had a busy time at the construction sites for the first half of 2020. Then I left that company in August 2020. After that, I worked on my own as a free craftsman. I had some work assignments from larger companies, but eventually the impact of the pandemic started to appear since the beginning of 2021. I have much less work at the construction sites.

While Japanese on the outside may appear to be very friendly, at the same time the society is not very accepting of outsiders. This hostile work environment faced by Mr. Duan and the lack of trust is not an uncommon occurrence as reported by a number of those interviewed. Foreign workers are isolated and do not have access to sufficient support and help in case of trouble.

Mr. Kumar (RK) has similar tales of both the difficulty of living in Japan and dealing with his Japanese colleagues.

(RK) I came to Japan in December 2019 as a cook at an Indian restaurant. But it did not open as scheduled in March 2020. I waited for more than half a year for the restaurant to open and it finally did in October of 2020. So, for several months, I was not paid. I was trying to look for other jobs, but my working visa is restricted to working at that restaurant only. The restaurant is in a remote resort area with a hot spring spa.

My lack of ability in Japanese prevents me from communicating with my colleagues much and they do not understand English. I have a feeling that the owner hired me because he wanted to appeal to the customers that bis restaurant offers something real from India. My face is the best advertisement for him. 
28 The Plight of Foreign Workers in Japan: Their Stories Speake for Themselves

Mr. Kamel (AD) recounts the poor living conditions he and colleagues experienced while serving as interns.

(AD) We are interns working on small farms which is situated in the rural area. The owner of the farm asked us to sign a contract with him to rent his house. Eight of us, four males and four females, have to share three bedrooms. Two guys have to sleep on the floor of the living room. We have only one toilet. He took us to a supermarket for shopping twice every week. We do not speak much Japanese so we have difficulty in looking for other apartments though the rent is higher than normal. Besides, we have to work overtime, and it is convenient for us to live near the farm..."

Both short-term and long-term residents are often treated as guest helpers, rather than as permanent members of the country. Dasgupta (2019), postulates that one of the issues is the interpretation of the word "assimilation." The stated goal of the immigration authority, for example, is to "help foreign workers assimilate" into Japanese society. The word "assimilation," when used by states, however, often has varying definitions. Sometimes, it is used in the sense of the more appropriate "adaptation," where the migrant is helped by the state to adapt to life in a new country with a different set of norms. However, given the Japanese state's historical emphasis on racial homogeneity, it must be said that the word "assimilation" might be meant literally, as a means of eliminating difference by "encouraging" the migrant to subscribe to the dominant social mores of the host society (Dasgupta, 2019).

The adage "the nail that sticks up gets hammered down" often associated with Japan is particularly relevant to foreign workers in Japan. Criticism of management and attempts to improve working conditions are perceived as a threat to management and the way of doing business. The friction created in Mr. Duan's company created by management's fear that foreign workers in the company would organize to demand changes is not an uncommon phenomenon.

Mr. Miller's experience working as an English teacher is evidence of the difficulty working in a Japanese organization and that despite living in Japan, one is always treated as a foreigner.

(JM) I came to Japan in the early 1990s, as an Assistant Language Teacher (ALT). I contracted with a company for English training and was dispatched to different junior and high schools. The Japanese teachers regard us as subordinates rather than professionals in English teaching. Sometimes, I was asked to keep silent for the whole class. I felt I was disrespected.

This tension between Japanese management and foreign subordinates is not an uncommon occurrence. In a survey of Japanese managers that examined working with foreign workers (Baseel, 2019), 34.3 percent reported that they feel intense stress because of the challenges the situation presents. When asked just what sort of difficulties they were grappling with, the managers had a long list of problems, with the top five being:

- $\quad$ Foreign workers are very self-assertive (46.1 percent)

- They don't understand things that are considered common sense to Japanese people (41.6 percent)

- They make aggressive demands for salary raises (40.7 percent)

- They have a low level of loyalty towards the company/organization (40.1 percent)

- It takes a long time to teach them how to do their jobs (40 percent) 
Further complicating the relationship between Japanese organizations and foreign workers is the lack of consistency in the administrative support process at the various levels of agencies. While The Japanese government, through the local governments, has increasingly providing administrative and language support to its residents, often in several foreign language, the information itself as well as dissemination are not adequate. As reported by several of the individuals interviewed, the information that is available to foreigners is often insufficient. The pandemic has exacerbated this problem as this is a time where information is most important.

(JM) During the pandemic, both I and my wife are required to teach online. But the problem is that different universities use different learning systems to teach. All the learning systems are customized, and there is no English version. We foreign teachers must remember how to operate and make the system function through the Japanese prompts. It is indeed a great challenge. Universities hold training sessions for teaching staff, but in Japanese only. The teaching manuals are in Japanese, too. In almost all cases, no administrative staff can speak English. We dare not complain because otherwise we might be replaced by other candidates. There are so many foreigners waiting for part time teaching positions at universities and colleges. Thus, we must remember hard how to use the system.

Furthermore, schools have integrated several classes into one to save money. Normally I have around 40 students in one class. During the pandemic, they reduced the number of courses I taught each week. But the number of students in one class grew to about 100 students. All my courses are oral English. The students are supposed to talk. With so many in my class and the complicated learning system, it is too difficult for me to engage in conversations with the students. The schools will not pay for tutors, so I must take care of issues that arise while teaching. They will often complain about their network problem, but sometimes I am not sure whether it is true or not. Every class makes me exhausted as more time is spent solving the computer problems rather than teaching English.

Since accepting foreigners is a national scheme, the Japanese government needs to both offer more administrative support to help its foreign residents to cultivate a better migration culture. Primary emphasis needs to be placed on helping migrants to adapt to life in a new country with a different set of norms, not simply treating them as a tool for business. The experience of Mr. Kumar, "I have a feeling that the owner hired me because be wanted to appeal to the customers that bis restaurant offers something real from India. My face is the best advertisement for him," should no longer be tolerated.

Despite the obstacles and social stigma to being a foreigner in Japan, some have planted permanent roots and started businesses and raising families. Notwithstanding, the pandemic has had an impact and the long-term effects are not yet known. Ms. Wang (XW) and her husband are just such a couple.

(XW) Most of our customers are Chinese. Before the pandemic, many foreign students at the Japanese language school and universities nearby came to our shop and restaurant. More than half of them were from China. They loved to come to our shop to search for the Chinese taste, so traditional food materials sold well. Sometimes, they would come to our restaurant for a gathering to celebrate birthdays or graduation. But after the pandemic, students were not able to enter Japan, and many gave up their plan to come to Japan to study and some foreign students could not come back to Japan if they had left on break. In addition, we could not get the products we ordered as normal. We had to wait for a longer time before they arrive. We just manage the small business, and the target customers are Chinese. Now, it is indeed difficult for us. Since our shop and restaurant next 
30 The Plight of Foreign Workers in Japan: Their Stories Speak for Themselves

door are on a small road, it would be much more expensive to move to a more convenient place. It would take more time for the business to be restored.

\section{Conclusion}

The foreign worker issue is one of the more challenging problems facing Japan today as policymakers look to find solutions to the social problems fostered by the low birth rate and lack of laborers in Japan. Understanding the issue from the perspective of the foreign worker will add to the discussion and this study has highlighted several concerns to be addressed. Our analysis of a sample of foreign workers in Japan has found that their economic and social conditions are less than ideal. Foreign workers are perceived as outsiders by the Japanese and quite often there appears to be blatant prejudice toward these individuals. There is sufficient evidence that the identities approach is the dominant factor affecting atttitiudes toward immigrants.

Perhaps he main contributing factor to the current state of affairs is that Japan remains both a mono-lingual and mono-cultural society and it still a big challenge for Japan society to accept the diverse nature of foreigners. Cultural restrictiveness needs to be removed if real globalization is to be achieved in Japan and assimilation, which has been the general policy towards foreigners, needs to not only be rhetoric, but put into practice. Foreign workers should not be treated as temporary labor but should be considered as part of Japanese community. In addition, administrative support is dispensable if the purpose of the national scheme is to help them to get integrated into the local community.

Yamawaki and White (2020) point out, "the nation, whose economy is struggling and whose population is rapidly aging, will clearly need to rely on immigration in the years to come. Still, Japan should not take a strictly economic position as it pertains to immigration ...the topic of immigration in Japan has been swept under the rug for too long and it should no longer be a taboo subject."

It is time for Japanese companies and society to reconsider issues related to foreign workers and reinforce laws and regulations which could help in dealing with cultural diversity to enable these workers to make a long-term contribution to the country. Japanese companies should invest more to take care of the psychological needs of foreign workers and make them feel secure both in the workplace and the local community. This will help decrease departures of foreign workers and serve as a key to a steady and long-term labor supply necessary for further development of the company and country. If Japan wants to accept more foreign workers to boost its economy and realize faster progress in globalization more efforts need to be made at both the national and local levels. 


\section{References}

Aboueldahab, N. (2021). Social Protection, not just legal protection: Migrant laborers in the Gulf. Brookings. https://www.brookings.edu/research/social-protection-not-just-legal-protection-migrant-laborers-inthe-gulf

ASSC Foreign Workers Round Table Activity Report. (2020). The Global Alliance for Sustainable Supply Chain. https://g-assc.org/wp-content/uploads/2020/09/ASSC_Foreign_Workers_Round_Table_2020_EN_ v1.0_20200331.pdf

Baseel, C. (2019). Over 30\% of Japanese managers feel intense stress from working with foreigners: survey. Japan Today. https://japantoday.com/category/features/lifestyle/over-30-of-japanese-managers-feelintense-stress-from-working-with-foreigners-survey

Bhandari, D., Kotera, Y., Ozaki, A., Abeysinghe, S., Kosaka, M., \& Tanimoto, T. (2021). COVID-19: challenges faced by Nepalese migrants living in Japan. BMC public health, 21(1), 752. https://doi.org/10.1186/s12889-021-10796-8

Bhattacharjee, S. (2014). Legal Protection for Migrant Trainees in Japan: Using International Standards to Evaluate Shifts in Japanese Immigration Policy. University of Pennsylvania Journal of International Law. 35 (4): pp. 1149-1173.

Business \& Human Rights Resource Centre (BHRR Center). (2021). Japan: Foreign workers first to lose jobs amid covid-19 outbreak. https://www.business-humanrights.org/en/latest-news/japan-foreign-workers-firstto-lose-jobs-amid-covid-19-outbreak/

Carrigan, L. (2018). New Specified Skills Visa for Japan: Your Questions Answered. https://blog.gaijinpot.com/new-specified-skills-visa-for-japan-your-questions-answered/

Chung, E. A. (2021). How South Korean demographics are affecting immigration and social change - demographics and the future of South Korea. Carnegie Endowment for International Peace. https://carnegieendowment.org/ 2021/06/29/how-south-korean-demographics-are-affecting-immigration-and-social-change-pub-8481 9

Citrin, J., and Sides, J. (2008). Immigration and the Imagined Community in Europe and the United States." Political Studies 56 (1): pp. 33-56.

Dasgupta, A. (2019). Japan's Immigration Policy: Turned Corner or Cul-De-Sac? The Diplomat. https://thediplomat.com/2019/02/japans-immigration-policy-turned-corner-or-cul-de-sac/

Davison, J. and Peng, I. (2021). Views on immigration in Japan: identities, interests, and pragmatic divergence, Journal of Ethnic and Migration Studies, 47:11, pp. 2578-2595.

Harding, R. (2019). Japan's population decline accelerates despite record immigration. Financial Times.https://www.ft.com/content/29d594fa-5cf2-11e9-9dde-7aedca0a081a

Fan, J, (2012). On Chinese Trainees and Interns in Japan. Beijing Law Review, 3(2): pp. 56-63.

Foreign workers in Japan and problems with Japan's foreign trainee program (2013). Facts and details.com. http://factsanddetails.com/japan/cat18/sub119/item1769.html

Furuoka, F and Kato, I. (2008), The 'Honne-Tatemae' Dimension in Japan's Foreign Aid Policy. Electronic Journal of Contemporary Japanese Studies. https://www.japanesestudies.org.uk/articles/2008/FuruokaKato. html

Fussell, E. (2014). Warmth of the Welcome: Attitudes Toward Immigrants and Immigration Policy in the United States. Annual Review of Sociology 40: pp..479-498.

Hamada, K. (2013). Public Opinions About Immigration in Japan. In Japanese Perceptions of Foreigners, edited by S. Tanabe, 27-41. Melbourn: Trans Pacific Press.

Gracia L. and Tran, H. (2019). Bridging the institutional gaps: International education as a migration industry. Journal of International Migration 57 (2): pp. 235-249

Hennings, M and Mintz, S. (2015). Japan's Measures to Attract International Students and the Impact of Student Mobility on the Labor Market. Journal of International and Advanced Japanese Studies 7(1): pp. 241251.

Hyun-ju, O. (2017). 1 in 9 female migrant workers subject to sexual abuse: Report. The Korea Herald. https://www.koreaherald.com/view.php?ud=20170620000876

Japan Student Services Organization (JASSO). (2020) https://www.jasso.go.jp/sp/

Japan International Training Cooperation Organization (JITCO). (2010) Technical Intern Training Guidebook. for Technical Intern Trainees. https://www.jitco.or.jp/download/data/guidebook_english.pdf

journals.tplondon.com/bc 
32 The Plight of Foreign Workers in Japan: Their Stories Speak for Themselves

Kakuchi S. (2019). Government tightens rules as foreign students 'disappear. University World News. https://www.universityworldnews.com/post.php?story=2019052116072279

Kenny, C. (2021). The Gulf Migration Model: Can It Be Sustained? Center For Global Development. https://www.cgdev.org/blog/gulf-migration-model-can-it-be-sustained

Kessler, A. E., and Freeman, G.P. (2005). Support for Extreme Right-Wing Parties in Western Europe: Individual Attributes, Political Attitudes, and National Context. Comparative European Politics 3 (2): pp. 261-288.

Kopp, R. (2014). Honne and Tatemae, Japan. Japan Intercultural Consulting. https://www.japanintercultural. $\mathrm{com} / \mathrm{en} /$ news/default.aspx?newsID $=293$

Koizumi, M, Nagata, K, Sugiyama, S. (2019). Foreign Workers are on the Way, but are Japanese Businesses Ready? Japan Times. https://www.japantimes.co.jp/news/2019/03/31/national/foreign-workers-wayjapanese-businesses-ready/\#.XNpTaLmP6dI

Mainichi Shimbum. (2018). Upper House Enacts Bill to Accept More Foreign Workers Despite Opposition Resistance. https://mainichi.jp/english/articles/20181208/p2a/00m/0na/001000c

Meuleman, B., E. Davidov, E, and Billiet, J. (2009). Changing Attitudes Toward Immigration in Europe, 2002-2007: A Dynamic Group Conflict Theory Approach. Social Science Research 38 (2): pp. 352-365.

Milly, D. (2020). Japan's Labor Migration Reforms: Breaking with the Past? Migration Policy Institute. https://www.migrationpolicy.org/article/japan-labor-migration-reforms-breaking-past

Ministry of Foreign Affairs Japan. (2019). Visa, Work or Long-term stay. https://www.mofa.go.jp/j_info/ visit/visa/long/index.html

Ministry of Justice Japan. (2017). Analytical report of the foreign residents survey. https://www.moj.go.jp/ content/001249011.pdf

Nakamura, Y. (2021). Japan's pandemic baby bust seen pushing births below 800,000. Nikkei Asia. https://asia.nikkei.com/Spotlight/Society/Japan-s-pandemic-baby-bust-seen-pushing-births-below$800-000$

Serizawa, K. (2018). Japan Opening Up to Immigration. Nippon.com. https://www.nippon.com/en/ currents/d00427/japan-opening-up-to-immigration.html

Stokes, M. (2021). Migrants are doing the Jobs South Koreans sneer at. Foreign Policy. https:// foreignpolicy.com/2021/01/28/south-korea-migrant-workers

United Nations Department of Economic and Social Affairs, Population Division. (2015). World population prospects: The 2015 revision, key findings, and advance tables. Working Paper No. ESA/P/WP.24. http://esa.un.org/unpd/wpp/Publications/Files/Key_Findings_WPP_2015.pdf

Verité. (2018). Forced Labor Risk in Japan's Technical Intern Training Program: Exploration of Indicators among Chinese Trainees Seeking Remedy. https://www.verite.org/wp-content/uploads/2018/09/Forced-Labor-Risk-inJapans-TITP.pdf

Weekly Economist Online. (2020). One year after the lifting of the ban on immigrants, foreign workers who are in need because they have no jobs due to coronavirus. https://weekly-economist.mainichi.jp/articles/20200922/ se $1 / 00 \mathrm{~m} / 020 / 027000 \mathrm{c}$

Yamawaki, K and White, B. (2020). It is time for Japan to start talking about its immigration policy. Japan Times. https://www.japantimes.co.jp/opinion/2020/10/08/commentary/japan-commentary/timejapan-start-talking-immigration-policy/

Yoshikawa, Y. (2021). Protecting Japan's foreign workers amid the COVID-19 pandemic. East Asia Forum. https://www.eastasiaforum.org/2021/07/03/protecting-japans-foreign-workers-amid-the-covid-19pandemic/

Yolo Japan. (2021). Approximately $80 \%$ of foreign residents affect work due to the spread of coronavirus infection. https://prtimes.jp/main/html/rd/p/000000079.000015950.html)

Zhang, R. and McCornac, D. (2013). Intercultural Awareness via Improvements in Intercultural Communication: The Need for Change in Japan. Journal of Intercultural Communication, 32 (2): pp 25-32.

Zhang R and McCornac D. (2013). The Need for Private Universities in Japan to Be Agents of Change. International Journal of Educational Management 27 (6): pp 562-577.

\section{Border Crossing}

